\title{
Laboratory, Greenhouse, and Field Assessment of Fourteen Fungicides for Activity Against Claviceps africana, Causal Agent of Sorghum Ergot
}

\author{
Louis K. Prom, USDA-ARS, Southern Plains Agriculture Research Center, College Station, TX 77845; and \\ T. Isakeit, Department of Plant Pathology and Microbiology, Texas A\&M University, College Station, TX 77843
}

\begin{abstract}
Prom, L. K., and Isakeit, T. 2003. Laboratory, greenhouse, and field assessment of fourteen fungicides for activity against Claviceps africana, causal agent of sorghum ergot. Plant Dis. $87: 252-258$

Commercial formulations of 14 fungicides representing seven chemical classes were assessed in vitro and in vivo for activity against Claviceps africana, causal agent of sorghum ergot. All fungicides markedly reduced spore germination in vitro on water agar, with effective concentration $(\mathrm{EC})_{50}$ values (based on active ingredient) that ranged from $0.01 \mu \mathrm{g} \mathrm{ml}^{-1}$ for thiophanatemethyl and trifloxystrobin to $1.18 \mu \mathrm{g} \mathrm{ml}^{-1}$ for cyprodinil. In vivo assays included applications of fungicide on full bloom panicles of a male-sterile line, ATx623, and then inoculating panicles with a conidial suspension immediately after the fungicide had dried. In greenhouse trials and in the 2000 field evaluation, a single application of propiconazole, tebuconazole, triadimefon, myclobutanil, or azoxystrobin at a rate of $25 \mu \mathrm{g} \mathrm{ml}^{-1}$ markedly suppressed ergot severity on ATx623. In the 2001 field evaluation, tebuconazole applied at $25 \mu \mathrm{g} \mathrm{ml}^{-1}$ was most effective in reducing levels of ergot severity. Ergot control was greater when fungicides were applied at 25 $\mu \mathrm{g} \mathrm{ml}{ }^{-1}$ than at $5 \mu \mathrm{g} \mathrm{ml}^{-1}$. Generally, triazole and strobilurin classes of fungicide were more effective in controlling ergot than benzimidazole, anilinopyrimidine, ethylenebisdithiocarbamate (EBDC), pyridinamine, and organometallic classes. At the two fungicide rates used in this study, ergot severity increased between 7 and 10 days after inoculation. Results showed that in vitro fungicide screening by measuring spore germination inhibition was not a good predictor of performance in the field. Results from the field trials suggest that control, particularly under ergot-favorable environments, may require higher rates than used in this study.
\end{abstract}

Additional keywords: Claviceps species, Sorghum bicolor

Recent spread of sorghum (Sorghum bicolor L.) ergot from Asia and Africa to Australia and the Americas has prompted research into management strategies aimed at minimizing the impact of the disease. Three Claviceps species (anamorph Sphacelia sorghi) are known to cause sorghum ergot: C. africana Frederickson, Mantle, \& de Milliano, the most widespread of the species, is found on five continents; $C$. sorghi P. Kulkarni et al. is found in Asia; and C. sorghicola Tsukiboshi, Shimanuki, \& Uematsu is found only in Japan $(2,14,22)$. In the United States, C. africana was first observed in 1997 (10). The pathogen infects the unfertilized ovary, growing in that

Corresponding author: Louis K. Prom E-mail: lprom@cgru.usda.gov

This paper reports the results from experiments conducted in College Station and Weslaco, TX. The mention of a fungicide formulation does not constitute a recommendation or warranty of the product by the USDA.

Accepted for publication 7 October 2002.

Publication no. D-2002-1216-03R

This article is in the public domain and not copyrightable. It may be freely reprinted with customary crediting of the source. The American Phytopathological Society, 2003. tissue to form a fungal structure known as a sphacelium, which is composed of hyphae and primary conidia. Fertilized ovaries are resistant to infection. Secondary conidia are formed following the germination of primary conidia and are important for long-range dissemination of the pathogen and development of epiphytotics.

Male-sterile lines (A-lines) used for hybrid sorghum seed production are highly vulnerable to ergot because their pollen originates from other plants and environmental conditions may restrict the period when pollen is available for fertilization $(2,8)$. In addition to the direct loss resulting from the replacement of a seed with a fungal structure, the sphacelium produces a sticky honeydew that can interfere with harvest of remaining healthy seed on the panicle. Reports of yield losses in hybrid seed production fields range from 10 to $80 \%$ in India and 12 to $25 \%$ in Zimbabwe $(2,16)$. Ergot caused a total loss in a fallplanted hybrid seed production field in 1998 and 2001 in the Lower Rio Grande Valley of Texas (T. Isakeit, unpublished).

Fungicide protection of the unfertilized flower is one of the approaches used to control ergot in hybrid seed production fields and has advantages over cultural practices and pollen management (6). The contact fungicides mancozeb, captafol, and ziram were effective against $C$. sorghi in field trials in India (1). Recent research on chemical control of $C$. africana has focused on systemic fungicides. In field trials in Brazil, multiple applications of several triazole fungicides controlled ergot, but their activity was preventative rather than curative (15). Multiple fungicide applications are needed because flowering of the panicle is not simultaneous and plants may vary in the stage of flowering. However, multiple applications greatly increase production costs, and a single fungicidal application is preferable. Frederickson and Leuschner (6) found that one preventative application of benomyl at heading was effective, but McLaren (12) reported that several systemic fungicides failed to protect for the entire flowering period. There is a continuing need to identify fungicides that are effective with a single application.

Since 1997, propiconazole (Tilt) is the only fungicide labeled for control of sorghum ergot in the United States, and it is labeled for multiple applications. Propiconazole is one of the triazole class of fungicides and is prone to resistance development due to the single-site mode of action. A decreased sensitivity of several pathogens to propiconazole has been observed in Europe where this fungicide is used continuously (20), but has not been reported with $C$. africana. One strategy to prevent fungicide resistance is to use several fungicides with different modes of action to manage plant diseases (20). Thus, there is a need to identify other efficacious fungicides against ergot that could be used in rotation or combination with propiconazole in a resistance management program.

Since the approach of an ergot chemical control program is to prevent germination of conidia that land on an unfertilized flower, our objective was to initially screen candidate fungicides for their ability to prevent conidial germination in vitro. An additional objective was to assess the potential effects of a single fungicide application for control of ergot under greenhouse and field conditions using the male-sterile line ATx623. The fungicides chosen for this study were from several chemical classes, representing different modes of action, and include those with contact and systemic activity.

\section{MATERIALS AND METHODS}

Laboratory assays. Formulations of the 14 fungicides tested, chemical classes, and 
sources are listed in Table 1. The agar plate spore germination method was used to evaluate the effectiveness of these fungicides in vitro (9). Concentrations of fungicide (a.i.) tested were 0.04, 0.2, 1, 5, 25, and $125 \mu \mathrm{g} \mathrm{ml}^{-1}$. Each fungicide was mixed in sterile water and then incorporated into a flask containing sterile, molten $2 \%$ water agar to obtain the appropriate concentration. A $10-\mathrm{ml}$ aliquot of the mixture was dispensed into 9-cm-diameter petri dishes. Controls consisted of water agar only.

Macroconidia of C. africana (TX isolate) were obtained from newly formed fungal sphacelia in panicles of greenhouse-grown sorghum plants. Individual infected florets were dissected, suspended in $10 \mathrm{ml}$ of sterile water, and further diluted to obtain a conidial concentration of ca. $200 \mathrm{ml}^{-1}$. The spore suspension $(0.05 \mathrm{ml})$ was placed on four marked areas on the agar surface of a petri dish. Each petri dish represented an experimental unit, and five plates per treatment were used. Petri dishes were incubated at 22 $\pm 2^{\circ} \mathrm{C}$ for $24 \mathrm{~h}$ under ambient light. Germination of 100 conidia in each marked area was evaluated with a microscope at $\times 100$ magnification. Each germinated macroconidium produced a short, unbranched conidiophore bearing a secondary conidium. The experiment was repeated three times.

Greenhouse experiments. Seeds of the male-sterile sorghum line ATx623 were planted in the greenhouse at $25 \pm 2^{\circ} \mathrm{C}$ in 20-cm-diameter plastic pots containing Metro-Mix growing medium (Scotts-Sierra Horticultural Products Company, Maryland, $\mathrm{OH}$ ) and thinned to one plant per pot. Experiments consisted of the same fungicide formulations used in the laboratory assays (Table 1). Each fungicide was applied at two rates, 5 and $25 \mu \mathrm{g} \mathrm{ml}^{-1}$. A treatment was represented by a fungicide and rate combination, and each treatment was replicated three times. The experiments utilized a randomized complete block design. A single fungicide spray schedule was applied at $100 \%$ anthesis. Fungicides were applied using a hand-held spray bottle until runoff, using a volume of 10 to $15 \mathrm{ml}$ per panicle. Panicles were allowed to dry for $1 \mathrm{~h}$ and then sprayed until runoff with a $C$. africana spore suspension $\left(1 \times 10^{6}\right.$ conidia per $\left.\mathrm{ml}\right)$. Control panicles were sprayed only with $C$. africana spore suspension. Treatments were replicated three times, and a single tagged and treated plant represented a replicate. Disease severity was based on the number of infected florets divided by the total number of florets per panicle multiplied by 100. Disease assessment was made at 7 and 10 days postinoculation (PI). The experiment was repeated three times.

Field experiments. Field trials were established in 2000 and 2001 at the Texas Agricultural Experiment Station near College Station. A male-sterile sorghum line, ATx623, was planted in field plots in May of both years. Each treatment (fungicide/rate combination) was replicated three times in a randomized complete block design. A replicate consisted of three adjacent plants at the same development stage. Fungicides were applied once on full bloom panicles using a hand-held spray bottle. Panicles were sprayed until runoff, allowed to dry for $1 \mathrm{~h}$, and then inoculated with a $C$. africana spore suspension $\left(1 \times 10^{6}\right.$ conidia per $\left.\mathrm{ml}\right)$. Control panicles were sprayed only with the spore suspension. In 2001, panicles were covered with a paper bag prior to flowering to prevent premature infection from inoculum originating from nearby plots. Fungicides were applied 21 June 2000 and 26 June 2001. Disease assessments were conducted at 7 and 10 days PI.

Statistical analyses. In the in vitro study, the spore germination data were analyzed using the command Proc Probit $\log 10$ (Statistical Analysis System 5, SAS Institute, Cary, NC) to determine the effective concentration $(\mathrm{EC})_{50}$ for each fungicide per experiment. The $\mathrm{EC}_{50}$ mean comparisons were conducted with Tukey's studentized range test at the 5\% probability level. Greenhouse and field data were normalized using the logarithmic transformation, then subjected to analyses of variance (ANOVA) to evaluate the effect of treatment (fungicide and rate combination), time of disease assessment, and their interaction. In the greenhouse data, there were homogeneity of error variances, and the data for the 2 years were combined. Due to heterogeneity of error variances in the field experiments, data for the 2 years were

Table 2. Analysis of variance for the effect of 14 fungicides on ergot (Claviceps africana) severity in the sorghum male sterile line, ATx623, planted in the field at College Station, TX ${ }^{\mathrm{w}}$

\begin{tabular}{|c|c|c|c|c|c|}
\hline \multirow[b]{3}{*}{ Source } & \multicolumn{5}{|c|}{ Mean square } \\
\hline & \multicolumn{2}{|c|}{ Greenhouse $^{\mathrm{x}}$} & \multicolumn{3}{|c|}{ Field } \\
\hline & df & ms & df & 2000 & 2001 \\
\hline Block & 2 & $0.1 \mathrm{~ns}$ & 2 & $0.06 \mathrm{~ns}$ & $0.40 \mathrm{~ns}$ \\
\hline Treatment ${ }^{\mathrm{y}}$ & 28 & $24.6 *$ & 28 & $29.49 *$ & $3.70 *$ \\
\hline Error (a) & 114 & 0.2 & 56 & 1.03 & 0.43 \\
\hline Time $^{\mathrm{z}}$ & 1 & $45.9^{*}$ & 1 & $62.36^{*}$ & $29.24 *$ \\
\hline Treatment $\times$ time & 28 & $1.2^{*}$ & 28 & $1.37 *$ & $0.41 *$ \\
\hline Error (b) & 144 & 0.1 & 58 & 0.49 & 0.08 \\
\hline
\end{tabular}

${ }^{\text {w}}$ Fungicides were applied once at two rates giving a total of 28 fungicide treatments. Trial was conducted for 2 years, 2000 and 2001, and data were $\log$ transformed before the analysis of variance. $\mathrm{CV}=14.4$ and $8.0 \%$ for the field data of years 2000 and 2001, respectively, and CV $=13.9$ for the combined greenhouse data. ns $=$ not significant $(P>0.05) ; *$ highly significant $(P \leq 1 \%)$.

${ }^{x}$ Greenhouse data combined over 2 years.

$\mathrm{y}$ Treatment $=$ fungicide and rate combination.

$\mathrm{z}$ Time $=$ disease assessment dates $(7$ and 10 days postinoculation $)$.

Table 1. Effective concentration $\left(\mathrm{EC}_{50}\right)$ of several fungicides on germination of Claviceps africana spores on water agar ${ }^{2}$

\begin{tabular}{|c|c|c|c|c|}
\hline Common name & Chemical class & $\begin{array}{l}\text { Product name } \\
\text { and formulation }\end{array}$ & Source & $\mathbf{E C}_{50}$ \\
\hline Triadimefon & Triazole & Bayleton $50 \%$ DF & Bayer CropScience, Kansas City, MO & $0.09 \mathrm{c}$ \\
\hline Copper sulfate & Organometallic & Cuprofix 30 DG & Cerexagri Inc., Philadelphia, PA & $0.13 \mathrm{c}$ \\
\hline Fenbuconazole & Triazole & Enable $2 \mathrm{~F}$ & Dow AgroSciences LLC, Indianapolis, IN & $0.10 \mathrm{c}$ \\
\hline Trifloxystrobin & Strobilurin (oximinoacetate) & Flint $50 \mathrm{WG}$ & Bayer CropScience, Kansas City, MO & $0.01 \mathrm{c}$ \\
\hline Fluazinam & Pyridinamine & Fluazinam 500F & ISK Biosciences, Mentor, OH & $0.12 \mathrm{c}$ \\
\hline Tebuconazole & Triazole & Folicur $3.6 \mathrm{~F}$ & Bayer CropScience, Kansas City, MO & $0.12 \mathrm{c}$ \\
\hline Maneb & Ethylenebisdithiocarbamate & Maneb 75 DF & Cerexagri Inc., Philadelphia, PA & $0.08 \mathrm{c}$ \\
\hline Mancozeb & Ethylenebisdithiocarbamate & Manzate 75 DF & Griffin LLC, Valdosta, GA & $0.06 \mathrm{c}$ \\
\hline Myclobutanil & Triazole & Nova $40 \mathrm{~W}$ & Dow AgroSciences LLC, Indianapolis, IN & $0.58 \mathrm{~b}$ \\
\hline Mancozeb & Ethylenebisdithiocarbamate & Penncozeb 75 DF & Cerexagri Inc., Philadelphia, PA & $0.07 \mathrm{c}$ \\
\hline Azoxystrobin & Strobilurin (beta-methoxyacrylate) & Quadris 2.08 F & Syngenta Crop Protection Inc., Greensboro, NC & $0.08 \mathrm{c}$ \\
\hline Propiconazole & Triazole & Tilt $3.6 \mathrm{~F}$ & Syngenta Crop Protection Inc., Greensboro, NC & $0.02 \mathrm{c}$ \\
\hline Thiophanate-methyl & Benzimidazole & Topsin M 70\% WP & Cerexagri Inc., Philadelphia, PA & $0.01 \mathrm{c}$ \\
\hline Cyprodinil & Anilinopyrimidine & Vangard $75 \mathrm{WP}$ & Syngenta Crop Protection Inc., Greensboro, NC & $1.18 \mathrm{a}$ \\
\hline
\end{tabular}

${ }^{\mathrm{z}} \mathrm{EC}_{50}=$ concentration that inhibits $50 \%$ germination. The mean $\mathrm{EC}_{50}$ of each fungicide for the three experiments (15 replications per fungicide) was determined using Proc Probit (Statistical Analysis System 5, SAS Institute, Cary, NC). Means in a column followed by the same letter are not significantly different, Tukey's studentized range test at $P=0.05$. 
analyzed separately. Mean comparisons for greenhouse and field data were conducted with Tukey's studentized range test at the $5 \%$ probability level.

\section{RESULTS}

Laboratory assays. Germination of $C$. africana macroconidia was significantly inhibited in vitro by the various fungicides (Table 1). Thiophanate-methyl and trifloxystrobin exhibited the lowest $\mathrm{EC}_{50}$ values $\left(0.01 \mu \mathrm{g} \mathrm{ml}^{-1}\right)$, whereas cyprodinil exhibited the highest $\mathrm{EC}_{50}\left(1.18 \mu \mathrm{g} \mathrm{ml} \mathrm{ml}^{-1}\right)$. Among the triazole class of fungicides, myclobutanil had an $\mathrm{EC}_{50}$ value $(0.58 \mu \mathrm{g}$ $\mathrm{ml}^{-1}$ ) significantly greater than the others. There were no significant differences in the $\mathrm{EC}_{50}$ values of the EBDC fungicides, maneb and mancozeb (Manzate and Penncozeb formulations). Similarly, $\mathrm{EC}_{50}$ values of the strobilurin fungicides, trifloxystrobin and azoxystrobin, were not significantly different. The triazole fungicides, tebuconazole, fenbuconazole, triadimefon, and myclobutanil, had $\mathrm{EC}_{50}$ values greater than that of the EBDC fungicides maneb and mancozeb (Manzate and Penncozeb formulations).
Greenhouse experiments. Main effects of treatment and time and the treatment $\times$ time interaction were highly significant (Table 2). Compared to the control, a single application of triadimefon, trifloxystrobin, fluazinam, tebuconazole, azoxystrobin, and propiconazole at 5 and $25 \mu \mathrm{g} \mathrm{ml}^{-1}$ and fenbuconazole, copper sulfate (Cuprofix formulation), mancozeb (Manzate and Penncozeb formulations), maneb, and myclobutanil at $25 \mu \mathrm{g}$ $\mathrm{ml}^{-1}$ significantly reduced levels of ergot severity when plants were evaluated at 7 and 10 days PI (Fig. 1). Ergot severities
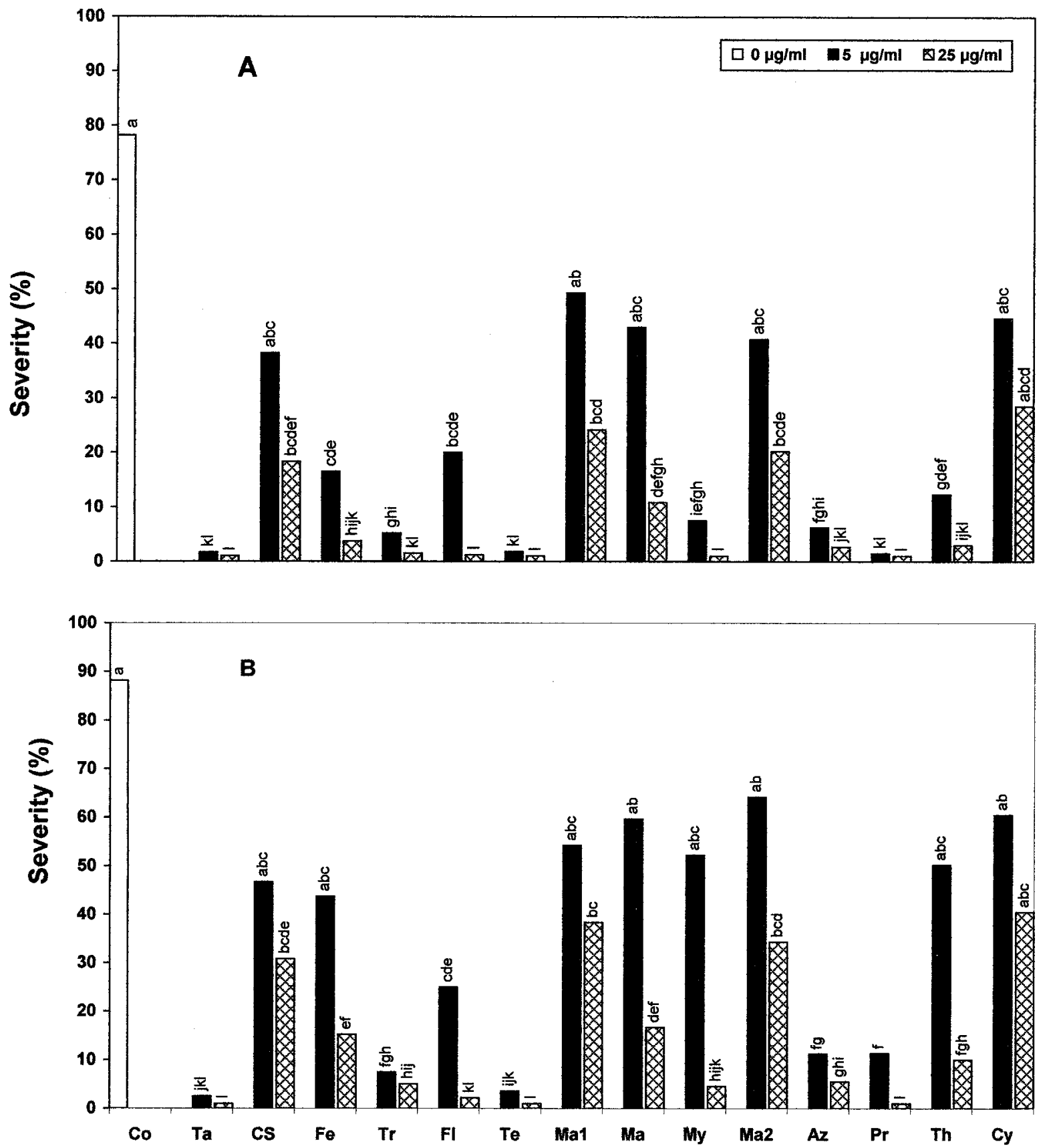

Fig. 1. Percent severity of ergot on male-sterile sorghum line ATx623 sprayed once at concentrations of 0,5 , and $25 \mu \mathrm{g} \mathrm{ml}{ }^{-1}$ with 14 fungicides and a control treatment labeled as $\mathrm{Co}=\mathrm{Control}, \mathrm{Ta}=$ Triadimefon, $\mathrm{CS}=$ Copper sulfate, $\mathrm{Fe}=$ Fenbuconazole $, \mathrm{Tr}=\mathrm{Trifloxystrobin}, \mathrm{Fl}=\mathrm{Fluazinam}, \mathrm{Te}=\mathrm{Tebucona}-$ zole, Ma1 = Mancozeb (Manzate), Ma = Maneb, My = Myclobutanil, Ma2 $=$ Mancozeb $($ Penncozeb) Az $=$ Azoxystrobin, $\mathrm{Pr}=\mathrm{Propiconazole}, \mathrm{Th}=\mathrm{Thio}-$ phanate-methyl, and $\mathbf{C y}=$ Cyprodinil evaluated at $\mathbf{A}, 7$ and $\mathbf{B}, 10$ days postinoculation in greenhouse. Data combined over 2 years. Comparisons were conducted with Tukey's studentized range test. Bars in a graph with the same letters are not significantly different at $P=0.05$. 
in control plants at 7 and 10 days PI were 78 and $89 \%$. Cyprodinil applied at both rates and copper sulfate, mancozeb (Manzate and Penncozeb formulations), and maneb applied at $5 \mu \mathrm{g} \mathrm{ml}^{-1}$ were the least effective in reducing ergot severity. The most efficacious fungicides were triadimefon, trifloxystrobin, tebuconazole, azoxystrobin, and propiconazole, giving a control ranging from 90 to $99 \%$ (Fig. 1). Disease control was greater with application of $25 \mu \mathrm{g} \mathrm{ml}^{-1}$ than with $5 \mu \mathrm{g} \mathrm{ml}{ }^{-1}$.
Field experiments. Main effects of treatment and time and the treatment $x$ time interaction also were highly significant under field conditions (Table 2). Again, the relative performance of each fungicide at 7 and 10 days PI was different, as revealed by the significant treatment $x$ time interaction. Generally, ergot incidence was lower when plants were evaluated at 7 days than at 10 days PI (Figs. 2 and 3 ).

In 2000, the mean disease severities of controls in the field plots were 36 and $72 \%$ of florets infected after 7 and 10 days, respectively (Fig. 2). These levels of disease incidence in the experimental plots were considered low. Triadimefon, tebuconazole, myclobutanil, azoxystrobin, and propiconazole applied at 5 and $25 \mu \mathrm{g} \mathrm{ml}^{-1}$, and fenbuconazole, trifloxystrobin, fluazinam, and thiophanate-methyl at $25 \mu \mathrm{g} \mathrm{ml}^{-1}$ markedly reduced ergot severity. Neither rate of copper sulfate, cyprodinil, mancozeb, and maneb markedly reduced the level of ergot severity.

In 2001, disease severities of controls in the field plots were 69 and $89 \%$ of
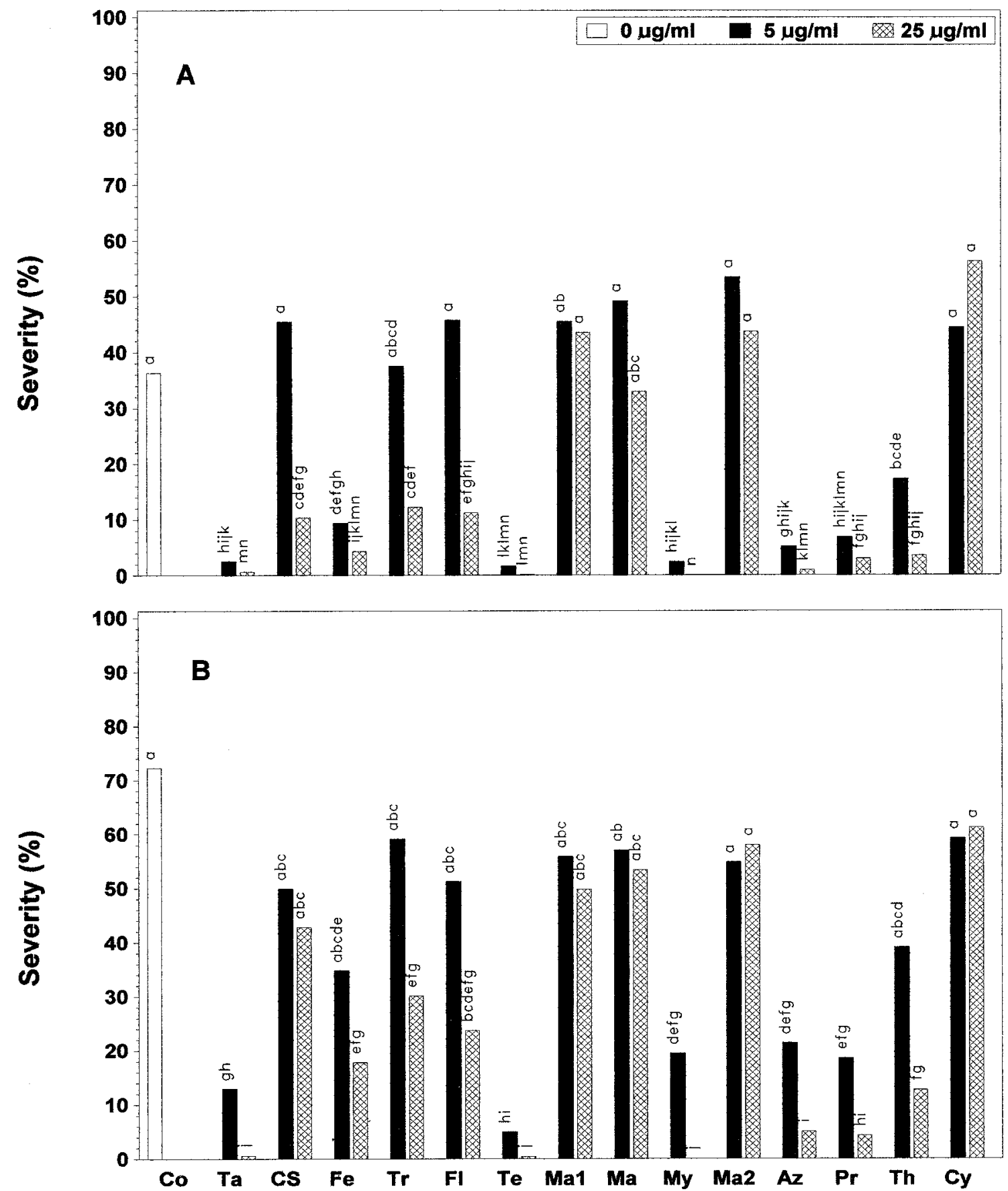

Fig. 2. Percent severity of ergot on male-sterile sorghum line ATx623 sprayed once at concentrations of 0,5 , and $25 \mu \mathrm{g} \mathrm{ml} \mathrm{l}^{-1}$ with 14 fungicides and a control treatment labeled as $\mathrm{Co}=$ Control, $\mathrm{Ta}=$ Triadimefon, $\mathrm{CS}=$ Copper sulfate, $\mathrm{Fe}=$ Fenbuconazole, $\mathrm{Tr}=\mathrm{Trifloxystrobin}, \mathrm{Fl}=\mathrm{Fluazinam}, \mathrm{Te}=\mathrm{Tebucona}-$ zole, Ma1 = Mancozeb (Manzate), Ma = Maneb, My = Myclobutanil, Ma2 = Mancozeb (Penncozeb), Az = Azoxystrobin, $\mathrm{Pr}=\operatorname{Propiconazole}$, Th $=$ Thiophanate-methyl, and $\mathrm{Cy}=$ Cyprodinil evaluated at $\mathbf{A}, 7$ and $\mathbf{B}, 10$ days postinoculation in College Station, TX, in 2000. Comparisons were conducted with Tukey's studentized range test. Bars in a graph with the same letters are not significantly different at $P=0.05$. 
infected florets after 7 and 10 days, respectively (Fig. 3). Tebuconazole at $25 \mu \mathrm{g}$ $\mathrm{ml}^{-1}$ gave the highest level of ergot control, followed by azoxystrobin and propiconazole, when plants were evaluated 7 and 10 days PI. The other fungicides applied at the two rates were not as effective in reducing ergot severity. As with the greenhouse results, ergot severity increased from 7 to 10 days PI. In both field experiments, the $25 \mu \mathrm{g} \mathrm{ml}^{-1}$ rate was more efficacious than $5 \mu \mathrm{g} \mathrm{ml}^{-1}$ (Figs. 2 and 3).

\section{DISCUSSION}

Systemic and contact fungicides, representing seven chemical classes, were evaluated for their potential to control $C$. africana. Fungicides were evaluated in vitro for their effect on spore germination as a quick, initial screen for antifungal activity. All fungicide formulations tested markedly reduced germination of $C$. africana. These included several triazole fungicides, which are generally known to inhibit hyphal growth but not spore germination (19). However, inhibition of spore germination by triazole fungicides was reported for other fungal species $(3,21)$, and this observation for $C$. africana is not unique. The contact fungicides mancozeb, maneb, fluazinam, and copper sulfate were the most inhibitory to spore germination. Dahlberg et al. (5) reported that other contact fungicides, captan and thiram, inhibited spore germination of $C$. africana in honeydew on the surface of sorghum seed. A fungicide seed treatment is one recommendation for preventing the introduction of ergot into
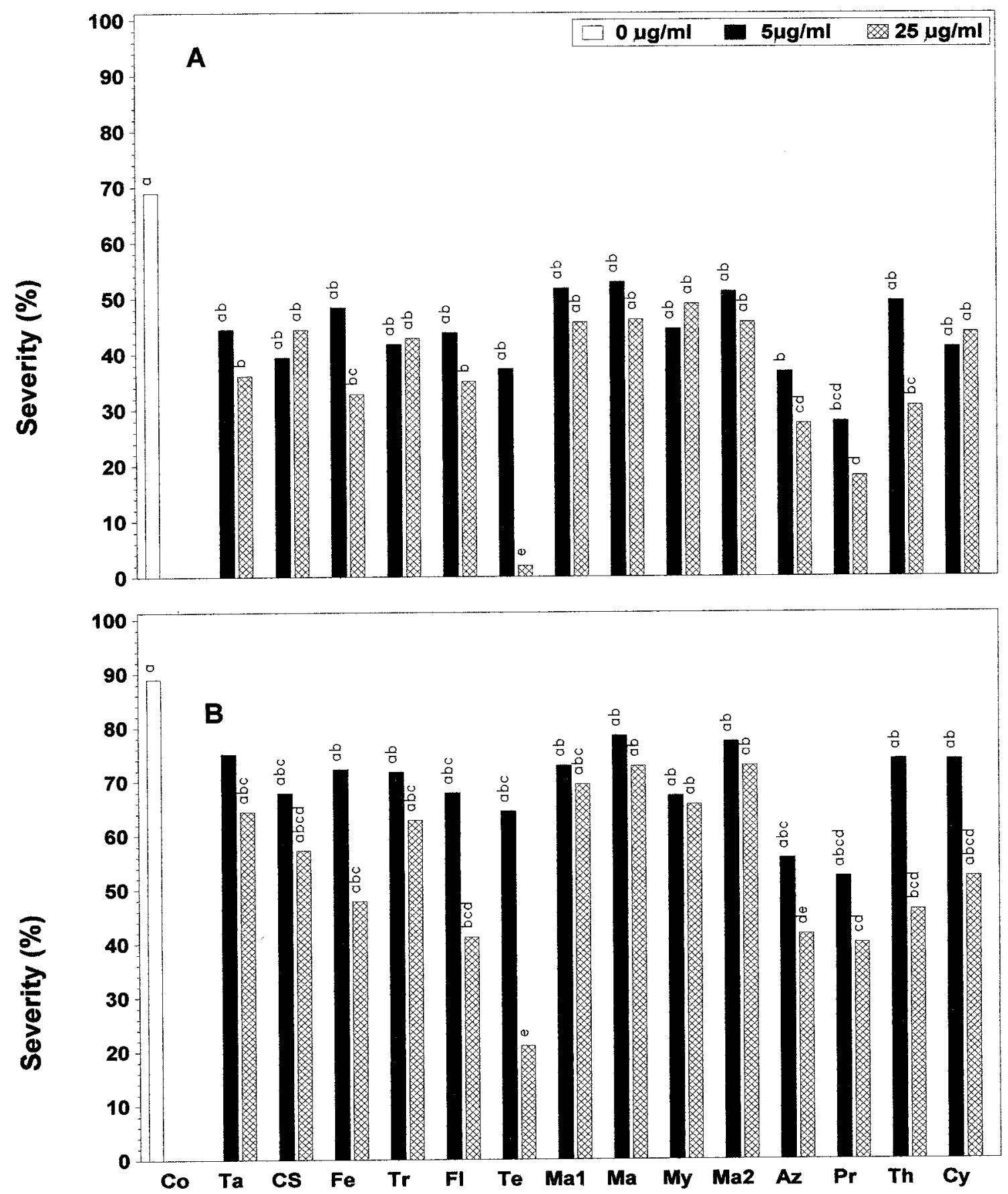

Fig. 3. Percent severity of ergot on male-sterile sorghum line ATx623 sprayed once at concentrations of 0,5 , and $25 \mu \mathrm{g} \mathrm{ml}{ }^{-1}$ with 14 fungicides and a control treatment labeled as $\mathrm{Co}=\mathrm{Control}, \mathrm{Ta}=$ Triadimefon, $\mathrm{CS}=$ Copper sulfate, $\mathrm{Fe}=$ Fenbuconazole $, \mathrm{Tr}=\mathrm{Trifloxystrobin}, \mathrm{Fl}=\mathrm{Fluazinam}, \mathrm{Te}=\mathrm{Tebucona}-$ zole, Ma1 = Mancozeb (Manzate), Ma = Maneb, My = Myclobutanil, Ma2 $=$ Mancozeb $($ Penncozeb), Az $=$ Azoxystrobin, $\mathrm{Pr}=\mathrm{Propiconazole}, \mathrm{Th}=\mathrm{Thio}-$ phanate-methyl, and $\mathbf{C y}=$ Cyprodinil evaluated at $\mathbf{A}, 7$ and $\mathbf{B}, 10$ days postinoculation in College Station, TX, in 2001. Comparisons were conducted with Tukey's studentized range test. Bars in a graph with the same letters are not significantly different at $P=0.05$. 
growing areas via movement of externally contaminated seed.

Although contact fungicides used in this study were the most potent inhibitors of spore germination in vitro, they were the least effective in preventing ergot development on panicles in the greenhouse and field. The disadvantages of contact fungicides in comparison with systemic fungicides are well known (7). Contact fungicides are generally less expensive than systemic fungicides and are suitable as rotation chemicals in a resistance management program. Three contact fungicides, mancozeb, captafol, and ziram, were effective against $C$. sorghi in field evaluations in India (1). Research on C. africana in several parts of the world has focused on systemic fungicides for ergot control (2). As with contact fungicides, sufficient panicle coverage with systemic fungicides under commercial conditions is a concern (2).

In vivo screening is considered to be the most accurate approach for predicting fungicide performance in the field, particularly with systemic fungicides (11), while in vitro screening tends to identify fungicides that are effective by maintaining a protective barrier against the pathogen on a host surface (17). Our results show that in vitro screening is not a reliable means for predicting fungicide performance for control of C. africana. For example, thiophanate-methyl and trifloxystrobin were the most inhibitory to spore germination but did not adequately control ergot in the field. Myclobutanil was more effective in controlling ergot in the greenhouse tests and field in 2000 than in inhibiting spore germination in vitro. Thus, we conclude that future screenings of potential fungicides for ergot control should utilize in vivo testing only.

Our greenhouse and field experiments represent optimal fungicide coverage of the panicle, since applications were made to individual panicles until runoff. The application rate of $25 \mu \mathrm{g}$ a.i. $\mathrm{ml}^{-1}$ used in these experiments corresponds to $33.5 \mathrm{~g}$ a.i. $\mathrm{ha}^{-1}$ in a volume of 1,342 liters $\mathrm{ha}^{-1}$. In Texas, the recommended rate of propiconazole is $51 \mathrm{~g}$ a.i. ha ${ }^{-1}$ in a volume of 140 liters ha ${ }^{-1}$ by ground application, or in a volume of 93 liters $\mathrm{ha}^{-1}$ by aerial application, with three applications allowed. Our objective was to identify potential fungicides for ergot control rather than to evaluate application volumes. Further work would be needed to determine fungicide efficacy at lower application volumes than used in this work. However, lower volumes may provide insufficient coverage of the panicle for disease control.

In greenhouse evaluations, the triazole (propiconazole, tebuconazole, triadimefon, myclobutanil) and strobilurin (azoxystrobin and trifloxystrobin) classes of fungicides were the most effective in suppressing ergot. The same fungicides were effective in the 2000 field trial, but not during the 2001 field trial. In both years, weather conditions at the time of inoculation and 5 days afterward were similar. In 2000 , the maximum and minimum temperatures ranged from 33 to $34^{\circ} \mathrm{C}$ and 22 to $25^{\circ} \mathrm{C}$, respectively, while in 2001 the maximum and minimum temperatures ranged from 34 to $35^{\circ} \mathrm{C}$ and 22 to $23^{\circ} \mathrm{C}$, respectively. There was no rain during this period in either year. In 2001, relative humidity was continuously measured in the plots, and periods during the evening where relative humidity was greater than $90 \%$ ranged from 6 to $9 \mathrm{~h}$. The increased amount of ergot in 2001 was attributable to ergot-infected sorghum in the immediate vicinity of these plots. Increased incidence of ergot on plants represents natural infections that occurred after artificial inoculation.

In the absence of complete ergot control, reduction of incidence to less than 5\% would not likely interfere with harvest. At 10 days PI, all fungicides applied at $25 \mu \mathrm{g}$ $\mathrm{ml}^{-1}$ failed to reduce ergot severity to this acceptable level. In similar experiments in Weslaco, TX, where there was a constant exposure of flowering panicles to inoculum originating from nearby plants, none of the fungicides applied once at $25 \mu \mathrm{g} \mathrm{ml}^{-1}$ sufficiently reduced ergot severity (data not shown). Other studies have employed higher rates. In field tests evaluated in Corpus Christi, TX, propiconazole at 125 and $250 \mu \mathrm{g} \mathrm{ml}^{-1}$ provided significant protection from ergot, even when panicles were inoculated with the pathogen up to 36 $\mathrm{h}$ after fungicide treatment (13).

The duration of ergot control was shown to increase with higher rates of either propiconazole or triadimefon (13). At a rate of $250 \mu \mathrm{g} \mathrm{ml} l^{-1}$, both fungicides suppressed ergot development up to 9 days PI, more so than lower rates of 62 and $125 \mu \mathrm{g}$ $\mathrm{ml}^{-1}$ (13). In this study, disease severity increased 7 days after inoculation at the 25 $\mu \mathrm{g} \mathrm{ml}^{-1}$ rate. This may be due to the differential effects of the fungicides or a delay in the development of infections. Therefore, it seems that the 10 days PI assessment time is more appropriate for determining the efficacy of fungicides than earlier assessment times. Also, there is the possibility that repeated applications of $25 \mu \mathrm{g} \mathrm{ml}^{-1}$ could adequately control the disease. However, additional applications would increase the production cost and could lead to resistance development.

Currently, propiconazole is the only fungicide labeled for use against sorghum ergot in the United States. Field trials in Corpus Christi showed that triadimefon provided better control than propiconazole at rates of 62,125 , and $250 \mu \mathrm{g} \mathrm{ml}^{-1}$ (13). In our greenhouse experiments and field evaluation in 2000, triadimefon and propiconazole were equally effective in suppressing ergot development. Propiconazole and tebuconazole have also been shown to be effective against $C$. africana in field trials in Brazil (15). In field trials involving other Claviceps species, Craig and Hignight (4) reported significant reduction in severity of ergot, caused by $C$. microcephala, on buffelgrass (Pennisetum ciliare) when triadimefon was applied twice a week. A single application of flusilazole, propiconazole, and tebuconazole was effective in reducing ergot of Kentucky bluegrass (Poa pratensis) caused by C. purpurea (18). Our data confirm that triazole fungicides have efficacy for ergot control in the field. Fungicides from this group, as well as strobilurin fungicides, may be good systemic candidates for a multiple application program designed to prevent resistance development.

Complete coverage of the panicle with triazoles or strobilurins at low application rates might be an economical and effective approach for chemical control of ergot in seed production fields located in the High Plains of Texas in years when environmental conditions are less favorable for infection. Low fungicide rates of triazoles and strobilurins may be effective in years that favor ergot development, if there is a low amount of inoculum available initially. However, these rates may be ineffective in growing areas with a climate more conducive to ergot, such as the Lower Rio Grande Valley of Texas.

Because the panicle does not flower simultaneously, multiple fungicide applications may be necessary, but they may not be economically feasible. Currently, low rates of fungicides could permit alternation with other fungicides that have different modes of action as a strategy for fungicide resistance management. Contact fungicides, used in combination with the triazole fungicides, may offer a means to economize on multiple applications of fungicides in addition to offering a strategy for resistance prevention. The efficacy of this combination of fungicides needs to be determined.

\section{ACKNOWLEDGMENTS}

We thank Gary N. Odvody, Juan Lopez, Jr., and Charles Howell for their valuable comments on the manuscript. We also extend our gratitude to Abdourhamane Issoufou Kollo, William L. Rooney, and Noe Motes Garcia for their technical assistance during the course of this study.

\section{LITERATURE CITED}

1. Anahosur, K. H. 1979. Chemical control of ergot of sorghum. Ind. Phytopathol. 32:487489.

2. Bandyopadhyay, R., Frederickson, D. E., McLaren, N., Odvody, G. N., and Ryley, M. J. 1998. Ergot: A new disease threat to sorghum in the Americas and Australia. Plant Dis. 82:356-367.

3. Clarkson, J. P., Kennedy, R., Phelps, K. Davies, J., and Bowtell, J. 1997. Quantifying the effect of reduced doses of propiconazole (Tilt) and initial disease incidence on leek rust development. Plant Pathol. 46:952-963.

4. Craig, J., and Hignight, K. W. 1991. Control of ergot in buffelgrass with triadimefon. Plant Dis. 75:627-629. 
5. Dahlberg, J. A., Peterson, G. L., Odvody, G. N., and Bonde, M. 1999. Inhibition of germination and sporulation of Claviceps africana from honeydew encrusted sorghum with seed treatment fungicides. Crop Prot. 18:235-238.

6. Frederickson, D. E., and Leuschner, K. 1997. Potential use of benomyl for control of ergot (Claviceps africana) in sorghum A-lines in Zimbabwe. Plant Dis. 81:761-765.

7. Fry, W. E. 1982. Principles of Plant Disease Management. Academic Press, New York.

8. Futrell, M. C., and Webster, O. J. 1965. Ergot infection and sterility in grain sorghum. Plant Dis. Rep. 49:680-683.

9. Gattani, M. L. 1954. The agar plate spore germination method for testing fungicides. Phytopathology 44:113-115.

10. Isakeit, T., Odvody, G. N., and Shelby, R. A. 1998. First report of sorghum ergot caused by Claviceps africana in the United States. Plant Dis. 82:592.

11. Knight, S. C., Anthony, V. M., Brady, A. M., Greenland, A. J., Heaney, S. P., Murray, D. C., Powell, K. A., Schulz, M. A., Spinks, C. A., Worthington, P. A., and Youle, D. 1997. Rationale and perspectives on the development of fungicides. Annu. Rev. Phytopathol.
35:349-372.

12. McLaren, N. W. 1994. Effect of systemic fungicides and timing of preventative sprays in the control of sugary disease of grain sorghum (Sorghum bicolor). S. Afr. J. Plant Soil 11:30-33.

13. Odvody, G. N. 2001. Development of plant disease protection systems for millet and sorghum in semi-arid southern Africa. Pages 3037 in: INTSORMIL 2001 Annual Report, INTSORMIL Pub. No. 01-5.

14. Pazoutová, S., Bandyopadhyay, R., Frederickson, D. E., Mantle, P. G., and Frederiksen, R. A. 2000. Relations among sorghum ergot isolates from the Americas, Africa, India, and Australia. Plant Dis. 84:437-442.

15. Pinto, N. F. J. A., Ferreira, A. S., and Casela, C. R. 1999. Chemical control of sugary disease of sorghum (Claviceps africana). Pages 158-160 in: Proc. Global Conf. Ergot Sorghum. C. R. Casela and J.A. Dahlberg, eds. EMBRAPA/INTSORMIL/ICRISAT Pub. No. 99-1.

16. Sangtrao, C. S., Indira, S., and Bandyopadhyay, R. 1999. Sorghum ergot in India. Pages 41-54 in: Proc. Global Conf. Ergot Sorghum. C. R. Casela and J. A. Dahlberg, eds. EMBRAPA/INTSORMIL/ICRISAT Pub. No. 99-1.

17. Sbragia, R. J. 1975. Chemical control of plant diseases: An exciting future. Annu. Rev. Phytopathol. 13:257-269.

18. Schultz, T. R., Johnston, W. J., Golob, C. T. and Maguire, J. D. 1993. Control of ergot in Kentucky bluegrass seed production using fungicides. Plant Dis. 77:685-687.

19. Sisler, H. D., and Ragsdale, N. N. 1984. Biochemical and cellular aspects of the antifungal action of ergosterol biosynthesis inhibitors. Pages 257-282 in: Mode of Action of Antifungal Agents. A. P. J. Trinci and J. F. Ryley, eds. Cambridge University Press, Cambridge.

20. Staub, T. 1991. Fungicide resistance: Practical experience with antiresistance strategies and the role of integrated use. Annu. Rev. Phytopathol. 29:421-442.

21. Tepper, B. L., and Yoder, K. S. 1982. Postharvest chemical control of Penicillium blue mold of apple. Plant Dis. 66:829-831.

22. Tooley, P. W., O'Neill, N. R., Goley, E. D. and Carras, M. M. 2000. Assessment of diversity in Claviceps africana and other Claviceps species by RAM and AFLP analyses. Phytopathology 90:1126-1130. 